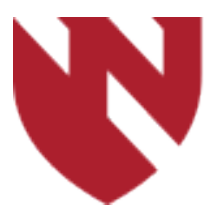

September 2020

\title{
Double Umbilical Cord Blood Transplantation in a Pediatric Patient: A First for Nebraska
}

\author{
Grace Murray \\ University of Nebraska Medical Center \\ Sachit Patel \\ University of Nebraska Medical Center
}

Tell us how you used this information in this short survey.

Follow this and additional works at: https://digitalcommons.unmc.edu/gmerj

Part of the Higher Education Commons, and the Medicine and Health Sciences Commons

\section{Recommended Citation}

Murray, G., , Patel, S. Double Umbilical Cord Blood Transplantation in a Pediatric Patient: A First for Nebraska. Graduate Medical Education Research Journal. 2020 Sep 29; 2(1).

https://digitalcommons.unmc.edu/gmerj/vol2/iss1/72

This Conference Proceeding is brought to you for free and open access by DigitalCommons@UNMC. It has been accepted for inclusion in Graduate Medical Education Research Journal by an authorized editor of DigitalCommons@UNMC.For more information, please contact digitalcommons@unmc.edu. 
Double Umbilical Cord Blood Transplantation in a Pediatric Patient: A First for Nebraska

\section{Creative Commons License}

\section{(c) (1) $\Theta$}

This work is licensed under a Creative Commons Attribution-Noncommercial-No Derivative Works 4.0 License. 


\section{Table 1.}

Patient demographics and clinical characteristics.

\begin{tabular}{|c|c|c|}
\hline & $\begin{array}{c}\text { By Case }(n=47) \\
N(\%)\end{array}$ & $\begin{array}{c}\text { By Patient }(n=14) \\
N(5)\end{array}$ \\
\hline \multicolumn{3}{|l|}{ Gender } \\
\hline Male & $17(36.1)$ & $5(35.7)$ \\
\hline Female & $30(63.8)$ & $9(64.6)$ \\
\hline \multicolumn{3}{|l|}{$\mathrm{Age}^{1}$} \\
\hline $0-5$ & $19(40.4)$ & \\
\hline $6-10$ & $6(12.7)$ & \\
\hline $11-15$ & $11(23.4)$ & \\
\hline $16-20$ & $8(17)$ & \\
\hline $21+$ & $3(6.4)$ & \\
\hline Average & Mean $10 y$ & \\
\hline \multicolumn{3}{|c|}{ Clinical Characteristics } \\
\hline Seizure history² & & $5(35.7)$ \\
\hline Contractures & & $14(100)$ \\
\hline Photophobia & & $6(42.8)$ \\
\hline $\begin{array}{l}\text { Able to } \\
\text { ambulate }\end{array}$ & & $10(71.4)$ \\
\hline \multicolumn{3}{|l|}{$I Q^{3}$} \\
\hline$\leq 50$ & & $7(50)$ \\
\hline$>50$ & & $6(42.8)$ \\
\hline Mean $=55$ Medi & $\operatorname{ian}=50.5$ & \\
\hline
\end{tabular}

with adherence of monitors and skin tearing upon removal of adhesives. Other complications were patient specific and not related to SLS.

Conclusion: Patients with SLS typically require general anesthetics when undergoing diagnostic studies and procedures for symptom management. Our case series suggests that general anesthesia is well tolerated in this population. Important aspects of pre-anesthetic evaluation include history of seizure severity and control, neurocognitive assessment and skin examination. Intraoperative considerations include photophobia, difficulty securing PIVs and monitors, relative heat intolerance, hypohydrosis, and challenges with positioning, padding, and line placement due to contractures. The ichthyosis of SLS spares the midface eliminating difficulty in securing airway devices.

https://doi.org/10.32873/unmc.dc.gmerj.2.1.068

\section{Double Umbilical Cord Blood Transplantation in a Pediatric Patient: A First for Nebraska Grace Murray ${ }^{1}$, Sachit Patel ${ }^{1}$}

${ }^{1}$ University of Nebraska Medical Center, Department of Pediatrics

Mentor: Sachit Patel

Program: Pediatrics

Type: Case Report

Background: Unrelated umbilical cord blood (UCB) transplantation has been used as a hematopoietic stem cell source for 30 years. Compared to adult bone marrow and peripheral blood stem cells, UCB has more rapid availability, absence of donor attrition, and reduced risk of GVHD despite HLA disparity. Unfortunately for larger patients, a single UCB unit has an insufficient amount of total nucleated cells to support engraftment. The use of two well-matched UCB units has been shown to overcome this barrier.
Methods: Chemotherapy, Graft, Cord Blood Transplant. Consent was obtained to utlize this case for educational purposes.

Results: A 12 year-old presented with bleeding and weight loss and was found to have anemia, thrombocytopenia and leukocytosis. Peripheral smear demonstrated auer rods. He was diagnosed with acute myeloid leukemia (AML-M4). He successfully completed therapy with protocol AAML 1031 but relapsed seven months later. He achieved a second complete remission with protocol AAML 0523. Given his high risk disease and poor prognosis with chemotherapy alone, the patient was offered transplant. No suitable sibling or adult unrelated donors were found. He underwent mismatched double umbilical cord transplant. Complications included grade III aGVHD involving the skin and GI system, and CMV reactivation. Engraftment was achieved on day +27 . He is now 16 years-old with full donor chimerism and complete immune reconstruction, no findings of chronic GVHD and no disease relapse.

Conclusion: This was the first pediatric patient in Nebraska to have a successful double UCB transplant. Double cord transplant is an acceptable alternative when there is no sibling or unrelated donor match and when a single cord unit total nucleated dose is insufficient.

https://doi.org/10.32873/unmc.dc.gmerj.2.1.069

\section{Shwachman-Diamond Syndrome: First Successful Hematopoietic Stem Cell Transplant in Nebraska Grace Murray ${ }^{1}$, Sachit Patel ${ }^{1}$}

${ }^{1}$ University of Nebraska Medical Center, Department of Pediatrics

Mentor: Sachit Patel

Program: Pediatrics

Type: Case Report
Background: Shwachman-Diamond syndrome (SDS) is an autosomal recessive condition characterized by bone marrow dysfunction, pancreatic insufficiency, and skeletal abnormalities. Ninety percent of patients with SDS have a mutation in the SBDS gene on chromosome 7, while the other ten percent are diagnosed clinically. 